\title{
Simulation Based Measuring the Benefits of Converting to Lean Product Design and Development: A Case Study of Manufacturing Sector of Pakistan
}

\author{
Muhammad Sajid ${ }^{1 *}$, Ahmad Wasim', Salman Hussain', Mirza Jahanzaib' \\ 1 University of Engineering and Technology Taxila, Department of Engineering Management, Faculty of \\ Industrial Engineering, 47080 Taxila, Pakistan \\ * Corresponding author's e-mail: sajid.malik@uettaxila.edu.pk
}

\begin{abstract}
Designers are facing the principal problems of effective decision making at the initial design stage of product development, which ultimately contribute to profit loss, low quality and increased time to launch the product onto the market. It requires a lot of knowledge and experience. Tools are required to analyze and ensure that crucial decisions have strong foundation before implementation. Discrete event simulation provides such a tool and has got potential to assist in decision making before final implementation. This research work aims measuring the benefits of transformation to lean product development (LPD) via simulation. Simulink-MATLAB tool was used for this purpose. The whole work is limited to design and cost estimation cells of a manufacturing company and consists of two phases. The first phase deals with the assessment of current working model of design and cost estimation cells. The areas for improvements were recognized at this phase. The proposed model for transformation to LPD was developed in the second phase. Four lean enablers namely product values, knowledge-based engineering, setbased concurrent engineering and poke-yoke were incorporated to further enhance the operation of the proposed model. This research work constitutes a useful case for practitioners.
\end{abstract}

Keywords: decision making, discrete event simulation, lean product development, lean enablers

\section{INTRODUCTION}

Global competition has originated from the socio-technical effects that forced the organizations to adopt the approaches for product development with low cost, high quality and shorter lead time [1]. Such a challenging environment encourages the companies to discover improvement opportunities in their current product development process. Among different product development methods, lean thinking has been considered the most appropriate way to overcome the above-mentioned challenges. Lean thinking is the philosophy of maximizing the value while minimizing the waste [2]. It has provided substantial improvements and gains to manufacturing, management, product safety and health cares, amongst other sectors [3-6]. Most of the compa- nies have applied lean thinking to their manufacturing processes to enhance productivity $[7,8]$. Considerably less effort has been done to apply lean thinking in product development.

Currently, in any application of lean thinking approaches, lean product development (LPD) is of paramount significance. It was based on the Toyota's product development process [2] which focuses on three product development elements, namely (i) value (ii) knowledge and (iii) improvement. During the last two decades, many researchers worked on lean product development (LPD). Hoppmann et al., [9] developed a framework for organizing lean product development. A content analysis was used to explore the existing approaches and integrated them with a single, articulate framework consisting of eleven lean product development components. A theoretical 
investigation of components interdependencies was conducted to better understand the novel definition of lean product development. Al-Ashaab et al., [10] developed and applied the lean product development performance measurement tool. It helps to identify the position of an organization in the lean product development journey in relation to the lean principles. The developed tool was employed in two organizations (aerospace and automotive) in order to validate the accuracy of the tool in evaluating and describing the starting conditions for espousing lean principles and practices. Khan et al., [11] introduced the concept of value (first lean principle) in product development by describing that in any application of lean thinking, the first step is to define value. It demonstrated the need to identify and represent value from the product development perspective. A subjective and objective fuzzy based AHP (analytical hierarchy process) model was proposed by Aikhuele and Turan [12] with the objective of prioritizing the LPD practices. The proposed model was based on the newly defined evaluation matrix and it has the advantage of completely eradicating repetitive modification of data. Khan [13] constructed an innovative model which supports the implementation of lean thinking in product development. Through the collaboration of European manufacturing companies, the model provides the process for conceptual development of an engineering project. The constructed model was then implemented in two case studies. It was concluded that the LPD model addresses various industrial challenges including the customer value, communication, and innovation. By focusing on the conceptual design, the model is expected to reduce the design rework. Similar reviews of research progress in LPD can be found in the literature [14-23]. It provides the customers with most innovative products according to their interest. However, the literature review highlighted that the available tools that aim at measuring performance are focused on lean principles. They did not consider the lean tools, strategy, improvements, and even did not evaluate the product development system as a whole. Therefore, to address this need, a novel lean product development model has gained importance to improve the existing traditional manufacturing systems.

In order to check the efficiency and control of the developed tools, processes and system against the set target or current traditional manufacturing systems, performance measurement is necessary
$[24,25]$. Key performance indicator (KPI) was one of the most widely used tool for performance measurement in an organization[26]. Researchers have developed different tools for measuring the performance (qualitative/quantitative) of an organization in product development. Al-Ashaab et al., [10] used lean product development performance measurement tool to assess the current position of an organization in the lean journey. Griffin [27] used a matrix for measuring cycle time of product development. Haque and Moore [16] developed a performance matrix for measuring the performance (total cost, number of design changes, percentage of new parts and total value of engineering outputs) of the aerospace industry. Wasim et al., [28] used a matrix for communicating alternatives for assessing the relationship of values for different alternatives in product and process development. An AHP based quantification method was used to select the optimum solution (such as an alternative with maximum quantification number would be selected as an optimum solution). A performance measurement survey was conducted by Driva et al., [29] to improve the decision making during the product development process in manufacturing organizations. It is important to mention that the previously described performance measurement tools were based on the economic features, management satisfaction, time to market and number of trials before production. They did not focus on the operational performance (higher utilization rate, system value added time, system work in process time and lower total time in system, average waiting time and total number of resources) of product development system as a whole. It has been well documented that the financial results lag behind the operational improvements in product development [30]. While quantifying the success of product development, there is a need to go beyond the non-operational features. The operational features should also be included as well. Therefore, a need for a tool to address all the operational performances exists.

Furthermore, the decision to modify the current product development (PD) practices in a company is very difficult due to a substantial difference between the traditional (current) and proposed approaches. These differences make it difficult for top management to measure the benefits to be accomplished by executing the proposed model for manufacturing companies. At the end, the decision to implement the modified 
model must be constructed on the combination of faith, the experience of other manufacturing experts and universal rule of thumb on the expected benefits. For top management, this rule of thumb is not enough to prove them to implement the proposed PD system. What is desired is a tool to assist the top management in quantifying the benefits they are expecting to achieve by implementing the proposed model. It must empower the top management to measure the performance in absolute terms and, most prominently, comparison with the well under-stood current product development model that it is designed to replace. A hypothesis that discrete event simulation would provide such a tool was made in this research. A simulation measures the performance improvements that can be expected by applying the proposed model [31]. Finally, simulation through animation delivers the visual description to the top management of how the proposed system design would work.

From the above-mentioned literature, it was investigated that limited work has been done on the conceptual design stage of lean product development. Researchers mostly considered the nonoperational benefits (cost) of implementing lean product development. Operational benefits (utilization, work in process, number of resources used etc.) also play a vital role in assessing the efficiency of lean product development at this stage. Additionally, the literature showed that a need for using tools in order to assist the decision makers in assessing the benefits of modifying the models currently practicing before final implementation exists. This research work bridge this gap with the aim to measure the benefits of transforming to lean product development. Simulation models were developed to replicate the behavior of current and proposed approaches of company understudy. The proposed model was implemented in a manufacturing company of Pakistan. The company is famous for high-volume manufacturing of water pumps.

This research paper was organized as follows: section 2 illustrates the assessment of current working model following by section 3 , which discusses the proposed model. Section 4 explains the modelling and simulation experiments in which simulation models of current and proposed LPD models were developed and run. Discussion of results is mentioned in section 5 followed by section 6 which discusses the concluding remarks regarding research accomplishment.

\section{ASSESSMENT OF CURRENT WORKING MODEL}

The system under study is the manufacturing system of a private company in Pakistan. The company is famous for producing customized, quality products and for excellent services. The core work of the company is to design and cast the water pumps and valves for water and wastewater services. Sand casting process is employed to manufacture the products. The product development process consists of many steps including (i) product order receiving and mapping (ii) product design (iii) production (iv) machining (iv) cost accounting (v) quality testing (vi) packaging and transportation. The system used multiple, identical blocks and cells to perform different jobs during product development process. These cells are either fully staffed or shut down as product demand dictates. This research work links with design and cost estimation cells.

Additional features for current manufacturing system include the following. A customer places order via an electronic ordering system. The incoming product values are mapped with the previously available product design values in the knowledge database. If the product is the same as previously manufactured products then it is sent directly to a foundry block for production otherwise it is moved to the design department where the designer designed the product by adding essential values (form and features) into it. The designer forwarded the developed design to a foundry shop where its production started using the sand casting process. When the product is manufactured, it is sent to testing laboratory for conforming the mechanical properties required by the end-user. After casting and testing properties, the product was directed to production department where the product was machined and proper surface finish was performed in order to attain the required product geometry. If the cast product is one assembly, then it is directly sent to the cost estimation cell and if the machined part is the subassembly of the final product then it is directly forwarded to the assembly section where it is assembled with other products to form the final product and then sent to cost estimation cell. In the cost estimation cell, the cost estimator sets the cost of the product and the product cost data is sent to the finance cell and quality cell. In the quality cell, the product is passed through quality checks to confirm that the final product meets all 
the requirements demanded by the customer. If the product meets the target quality checks, then the product is stored in the storage cell for packing and shipment purpose. If the product fails to meet the quality checks, then it is considered as a defective part or scrapped. The schematic diagram of current working model of understudy manufacturing system is shown in Figure 1.

From the current model, it was found that there was no integration design and cost estimation cells, which resulted in high job floor trials due to the changes requirements to fulfill the target cost. Such job floor trials required considerable resources, which ultimately resulted in high profit loss. This challenge was addressed by transforming the current model to the LPD model described in the following section.

\section{PROPOSED MODEL}

Since there is an opportunity to modify the current working model of the manufacturing system, it should be noted that the existing system is already practicing some lean concepts such as flexible environment to meet the deviating demands of different products, each workstation is labelled with standardized working charts, visual control and 5S are being followed in the assembly cell and for parts stored in the exchange area and Poke-yoke principles for scanning each operation to ensure all parts are in a product con- tainer. In addition, the existing system is planning to implement 6-sigma technique for improving the process and eliminating defective parts from manufacturing to transactional and from product to service. The aforementioned lean concepts are being implemented when production starts. The company still needed lean tools for improving the capabilities of designers at the conceptual design stage of product development. It showed that the company has the potential to be transformed into the LPD model by implementing the certain actions. The developed framework for proposed model is shown in Figure 2. The author recommends the following modifications to the current working model.

\section{Integration of design and cost estimation cells}

The designer is asked to estimate the product cost while designing the product at the initial design stage. If it meets the target cost, then it is sent to the foundry block, otherwise the designer is required to remodify the design to meet the target cost. The integration of design and cost estimation cell will help in reducing the job floor trials and less time it will take to launch the product onto the market.

\section{Equip the designer with lean enablers}

In order to improve the end products and the competency of an organization to develop prod-

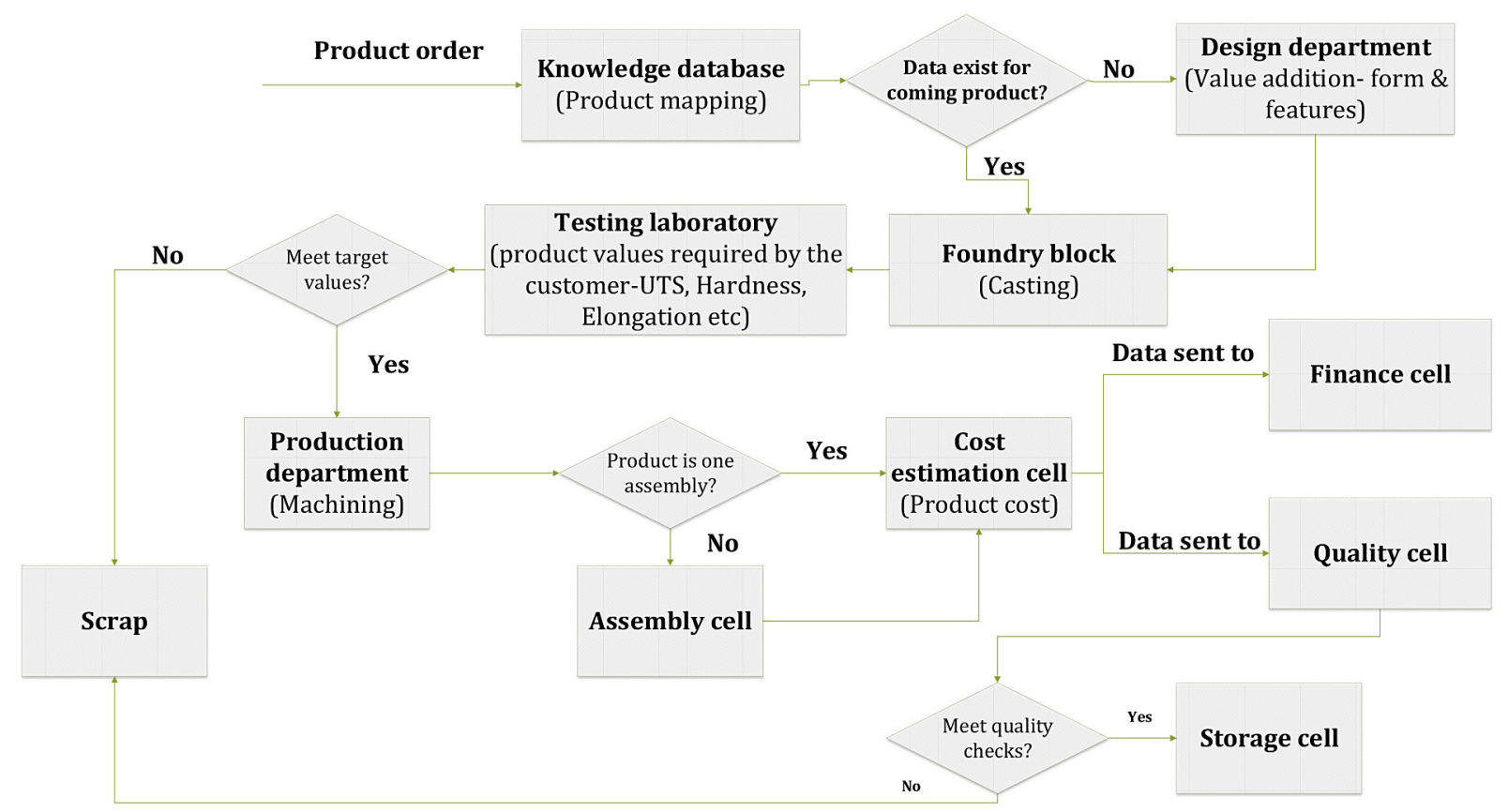

Fig. 1. Schematic diagram of working of current manufacturing system model 


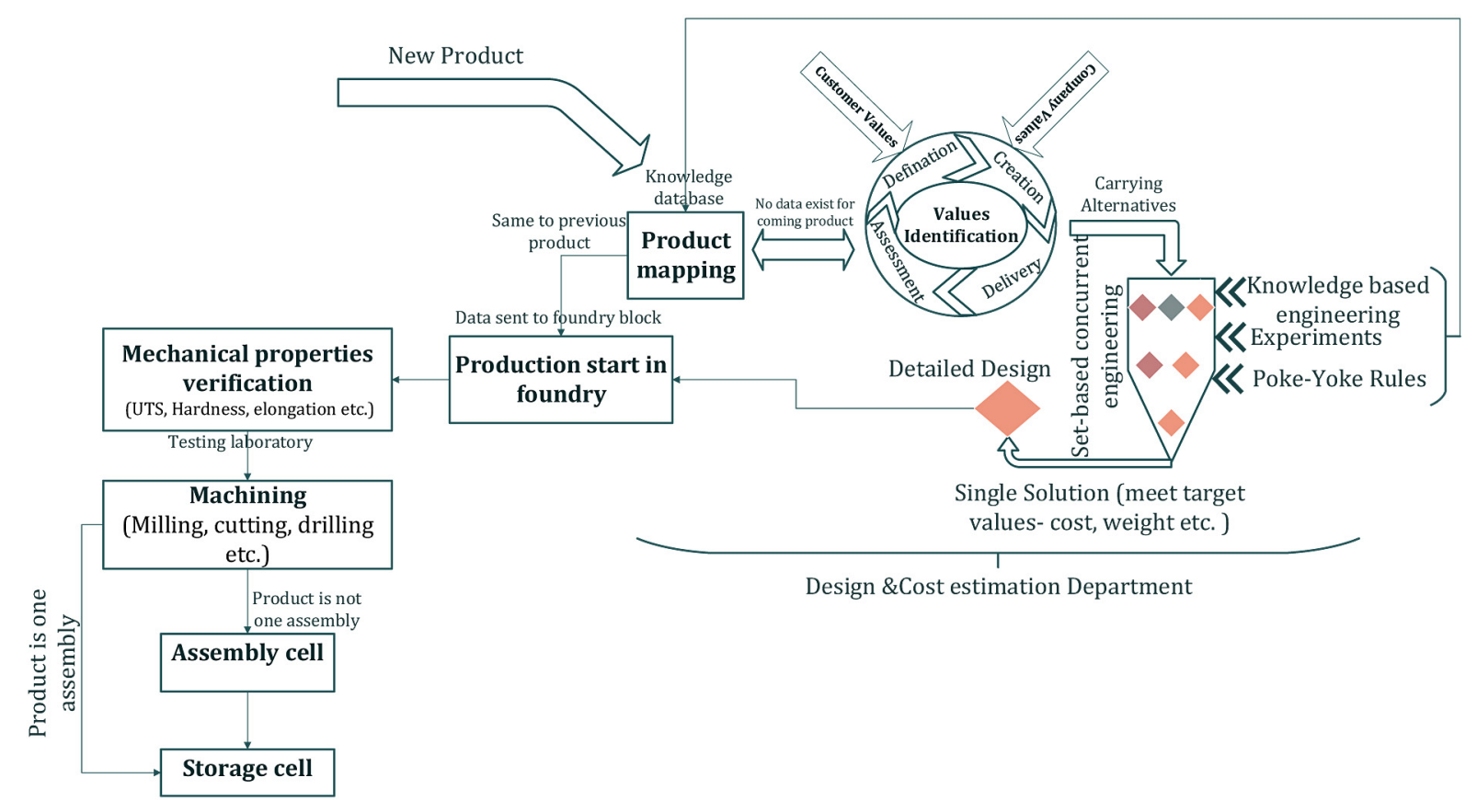

Fig. 2. Framework for proposed model

ucts, researchers have proposed that the application of lean thinking in product development will bring significant results $[11,32,33]$. It has provided considerable improvements and gains to manufacturing companies such as designer's utilization. In the proposed model, the authors planned to incorporate four lean enablers, namely (i) Product value (ii) Knowledge-based Engineering (iii) Set-based Concurrent Engineering and (iv) Poke-yoke (mistake proofing). Their description is given below:

\section{Product Value}

In today's customer-centered era, the product value has become the main concern for manufacturing companies. The first step in any application of lean thinking is to define value [11]. Product value lean enabler allows the designers to categorize and represent the values during product development. It is a value-added process of capturing and transforming value from the customer's minds to designers that would enable better elicitation of requirements and the development of value-focused products. According to Morgan and Liker [34], the definition of value has significant importance. Without proper understanding of values, an organization would struggle to identify value, communicate value effectively and developing product with a shear understanding of values in product development. In this research work, the value identification process adopted by
Mele [35] was divided into four phases namely (i) value definition (ii) value creation (iii) value delivery and (iv) value assessment with the aim to satisfy the interest of customers and all relevant stakeholders.

\section{Knowledge-based engineering}

Knowledge-based engineering (KBE) is used to support set-based concurrent engineering and product value lean enablers as it provides the information data regarding the product design. It provides the opportunities to companies to grow faster than their competitors and survive. The main objective of this lean enabler is to maximize the learning. It allows the designers to make more robust decision making in short time as it ensures the dynamical capture and reuse of the knowledge gained through the development of sets of alternative design solutions. KBE also comprises the knowledge life cycle, making sure knowledge is delivered to the right place and at the right time [19] .

\section{Set-base concurrent engineering (SBCE)}

Set-based concurrent engineering is considered as the core enabler, as it represents the process that guides the designer in developing products design under lean environment. It is defined as the process where different alternatives of solutions for product design are developed in parallel. On the basis of the knowledge gained through 
simulation, prototyping, design rules (poke-yoke rules) and experimentation, designers gradually narrow their sets of solutions with the progression of design until a final single solution is obtained.

\section{Poke-yoke (Mistake proofing)}

Poke-yoke lean enabler also supports SBCE. It is used to avoid mistakes at both conceptual and detailed design stage of product development. It helps the designer to avoid mistakes while making a decision regarding the product development alternative selection such as mistake elimination during product material selection, product design selection etc. For this purpose, poke-yoke rules (if-then), which cover each alternative solution, are developed. The designer keeps these rules in view while selecting a suitable alternative (single solution). An example of poke-yoke rule is given below:

Poke-yoke rule for casting material selection IF

Casting part is volute casing of pump assembly AND

Required assembly application area is high pressure water services

AND

Required tensile strength of casting is $>400 \mathrm{MPa}$ AND

Required hardness of material is $>=200 \mathrm{HBN}$ AND

Any additional rule

Than C9001 is selected material

C9001 is cast iron

Additional features of framework for proposed model (Figure 2) for LPD system can be described as below.

With the arrival of a new product, it is mapped with the previously developed products in the knowledge database. If it is the same product as the previously developed, then the product data is sent to the foundry after adding some necessary values (if they are demanded by the customer) and production starts. In case if there is no data exists, then it is directly send to design and cost estimation department, which is working under lean environment. In this department, the very first step is to identify the product values. The designers are asked to identify value (customer values, company values, other stakeholders) and set target against each value. Tools and approaches are developed in this model to identify the values.
Each designer is asked to design a set of alternative solutions to optimize (acceptable) product values. A novel set-based concurrent engineering lean enabler has been developed to help the designer in creating set of alternative solutions. On the basis of knowledge gained through knowledge-based engineering, simulation, prototyping, design rules (poke-yoke rules) and experimentation, designers gradually narrow their sets of solutions with the progression of design until a final single solution which meets the target values is obtained. Once a final design is selected, which remains the same throughout the product life cycle, a detailed product design analysis is conducted and the data is sent to foundry for production start using the sand casting process.

After casting and testing the required mechanical properties, the product is directed to the production department where different post-casting operations (cutting, milling, drilling etc.) are performed in order to attain the required product geometry. If a casted product is one assembly, then it is directly sent to the storage cell and if the machined part is the subassembly of the final product then it is sent to the assembly section where it is assembled with other products to form the final product and then sent to storage cell for packing and shipping purpose.

\section{MODELLING AND SIMULATION EXPERIMENTS}

A detailed simulation model was developed based on implementation of proposed modifications to measure the benefits. For this purpose, Simulink-MATLAB software was used. It starts with the model development for the current system, which was further modified to the LPD model. Extensive effort was made to verify and validate the input data where careful suggestions by experts were studied and a review of model performance and numerical outcomes was analyzed for the current system. The verification process ensures that the simulation model mimics the real world. In this process, various entities are traced from the point of creation to the end of the system. They include the checking of the codes, model logic and experimental conditions verifications. In order to verify that model replicates the real system, a detailed animation was used. Validation deals with the comparison of simulated results with the actual ones. The measures included 
that are included in this research work were designer's utilization, total time in system, average waiting time, system value added time, system work in process and number of resources used. Two sets of experiment were designed each representing different design assumptions. In the first model, the current system was designed without integration between the design department and cost estimation department. In the second model, a proposed system was designed which integrated the design and cost estimation cells under lean environment. Customer inter arrival time followed exponential distribution with mean 89 hours. The current system consisted of seven different designers having uniform processing time (maximum value: 28 days, minimum value: 3 days) and 3 cost estimators with a uniform processing time (maximum value: 2 days, minimum value: half day (12 hours). Starting with time zero, a warm up period was used which allows the system load itself with entities and consequently reach the steady state. A total number of four replications were carried out and model was run for a period of 104 days. Figure 3 shows the plot of average utilization of the designers as a function of time. A warm up period of 50000 minutes (35 days) was used. Table 1 shows the simulated results (averages) and the actual values of the existing model. It shows that the simulated values lies within the range of actual set values by the company personal, which validates the model.

\section{RESULTS AND DISCUSSION}

After verification and validation of the existing working model of product development, the proposed model for lean product development was evaluated. The relative impact of integrat- ing the design and cost estimation cells and their working under lean environment was analyzed. The benefits of integrating the design and cost estimation cells and their working using four lean enablers (product values, knowledge based engineering, set based concurrent engineering and poke-yoke) include the following:

- System utilization increased from 59.71\% to $73.79 \%$ which shows that the proposed system has a significant effect on utilization rate of designers and the system performance improved which revealed the LPD model effectiveness.

- Total time in system decreased from 24.9078 days to 22.8526 days. It is the time that a product spends in a system from the entering stage (new product arrival) to the leaving stage (final product after adding all values).

- Average waiting time of products decreased from 17.1026 days to 15.3160 days. It is the time that a product spends on a station in a system before processing starts.

- System value added time increased from 7.5365 days to 8.8052 days. It is the time that a designer spends while performing the value added activities on a product. It is also known as the value addition time.

- Designs work in process increased from 15.6691 to 8.073 days. It is the time for which the whole design remains under operation/work.

- Total number of resources used by the system decreased from nine to five. These resources are included the number of employees used by the LPD model.

The results comparison in Table 2 highlighted that for the first 104 days, the proposed lean product development model provided significant improved results and they are expected to increase along with
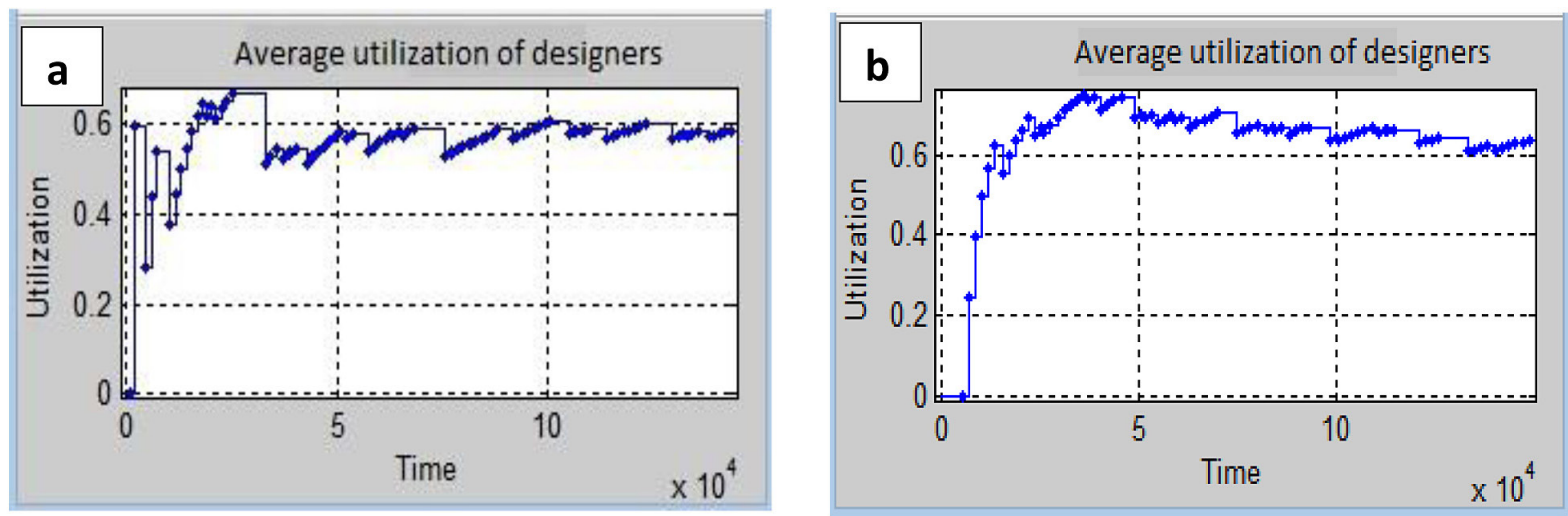

Fig. 3. Transient period analysis for average utilization of designers: (a) existing model, (b) proposed model 
Table 1. Performance measurement for existing system: Actual vs Simulated

\begin{tabular}{|l|c|c|}
\hline \multicolumn{1}{|c|}{ Performance measure } & Actual value & Simulated value \\
\hline Designer's utilization (\%) & $57-64$ & 59.71 \\
\hline Cost estimator's Utilization (\%) & $10-15$ & 12.94 \\
\hline Total time in system (days) & $20-25$ & 24.9078 \\
\hline Average waiting time (days) & $10-18$ & 17.1026 \\
\hline System Value added time (days) & $4-9$ & 7.5365 \\
\hline Designs work in process & $15-20$ & 15.6691 \\
\hline Total number of resources used & $5-10$ & 9 \\
\hline
\end{tabular}

Table 2. Benefits comparison of current and proposed LPD system

\begin{tabular}{|l|c|c|c|}
\hline \multicolumn{1}{|c|}{ OUTPUT } & Current System & Proposed LPD System & Percentage improvement \\
\hline System utilization & $59.71 \%$ & $73.79 \%$ & $19.08 \%$ \\
\hline Total time in system & 24.9078 days & 22.8526 days & $4.40 \%$ \\
\hline Average waiting time & 17.1026 days & 15.3160 days & $6.53 \%$ \\
\hline System Value added time & 7.5365 days & 8.8052 days & $14.40 \%$ \\
\hline Designs work in process & 15.6691 & 8.073 & $48.51 \%$ \\
\hline Total number of resources used & 9 & 5 & $44.44 \%$ \\
\hline
\end{tabular}

the designer experience of estimating the product cost while designing it under lean environment.

The performance enhancement represents the associated benefits of all of the changes incorporated in lean product development (LPD) model relative to current system. Although, the investigation did not isolate the benefits of each modification, certain benefits can be linked with specific changes:

- The benefits of integrating the design and cost estimation cells into one cell (design and cost estimation department, fig.3) were the elimination of their respective flow time and the freeing of three employees from the cost estimation cell and two from the design cells, enabling them to perform other works.

- It reduced the variability of supplier demand.

- The decrease in work in process inventory ensures the availability of floor space for other activities or operations.

For observable reasons of privacy, this research work did not provide access to the financial information that would be needed to convert the saving expected in working under lean enablers into economic and quality terms. However, as much as the research quantified these savings in physical quantities, many of these savings can be readily converted to financial values. For example:

- The savings in employees (4 people) can freely be described in monetary terms, both labor cost and total product cost.
- The reduction in job floor trials can be converted to Rupees based on the back ordering cost.

- The decrease in work in process inventory can be converted to inventory cost based on the inventory holding cost.

In addition to the benefits mentioned above, working under four lean enablers also provides many other benefits that directly or indirectly affect the key performance indicators (KPI) of the proposed model such as quality, cost and time. These are explained below:

- Value identification is the first principle of application of lean thinking. During the application of product value lean enabler, the designer was asked to take into account the customer values, company values and all other stakeholders' values that have link with the product. It led to the incorporation of all product stakeholders' values and formation of quality product.

- The application of knowledge base engineering ensures the knowledge identification, knowledge gaining, knowledge shearing, knowledge transformation and knowledge storage. It results in the formation of knowledge database of a specific product. This lean enabler ensures the information flow and communication between the departments, which leads to short response time to customers.

- Set-based concurrent engineering produces sets of alternative solutions, which are gradu- 
ally narrow down-with the help of knowledge, gained from the customers, companies, experimentation and prototyping- to a single solution, which remains unchanged throughout the product life cycle. It ensures an accurate decision making which ultimately results in reduced cost and development time.

- During product design and development, there are many chances of making mistakes accruing at both conceptual and detailed design stage. It leads to high job floor trials. In order to avoid these mistakes, poke-yoke was employed which helps in avoiding mistakes during material selection, process selection, machine selection and assessing the manufacturability of the products. It ultimately results in producing quality products with low cost and high quality.

- In addition to these, interrelationship exists between the adopted lean enablers such as setbased concurrent engineering used the knowledge gained through creation and identification of product values, knowledge-based engineering and Poke-yoke. Knowledge-based engineering also supports the product value lean enabler as it helps in identification of customer and company values. It ensures the motivation to incorporate maximum and accurate knowledge into the product and it will help in producing quality products.

\section{CONCLUSIONS}

A simulation-based lean product development (LPD) model was proposed and the benefits of integrating lean product design and development were assessed in this research work. Discrete event simulation (using Simulink tool) was revealed as a tool to quantify the benefits of the proposed LPD model. In this research work, the use of simulation deliver more reliable estimates of savings (in cost), resources and improvements in performance statistics than that attainable by using the proposed LPD model. In the system under study for predevelopments, simulation has shown the impact of the proposed LPD model in terms of improvements in utilization, total time in system, waiting time, value added time, work in process time and total number of resources used.

The proposed LPD model integrates the design and cost estimation cells into one department namely design and cost estimation department.
The proposed LPD model enabled the designer to estimate the cost while designing the product at the initial design stage. Four lean enablers namely (i) product value, (ii) knowledge based engineering, (iii) set-based concurrent engineering and (iv) poke-yoke were incorporated in this research work. These lean enablers help the designers in design and cost estimation department such as product value help the designer in identifying and creating product values; Set-based concurrent engineering enable the designer to assess the best possible solution by narrowing down the sets of alternative solutions; Knowledge-based engineering and poke-yoke support set-based concurrent engineering because they provide the necessary information, knowledge, and design rules (pokeyoke) that helps the designer in eliminating weak solutions from a set of alternative solutions for a product design. Knowledge-based engineering lean enabler was used to capture the best design practices and engineering expertise into a corporate knowledge base. Poke-yoke lean enabler was used to eliminate the mistakes during product development at both conceptual and detailed design stage. This research work provides significant advantage for manufacturing companies considering the implementation of the proposed LPD model. It compares the performance of the current and proposed working model of a manufacturing company for product development at the initial design stage under lean environment. The performance analysis and the developed model provide the basic information to higher management who wants to access the overall economic, tactical and viable benefits.

\section{REFERENCES}

1. Jani, S.Y. and T. Desai, Review of lean manufacturing practices-critical success factors and performance measures for SMEs. International Journal of Quality and Innovation, 2016. 3(1), 30-41.

2. Womack, J.P. and D.T. Jones, Lean thinking: banish waste and create wealth in your corporation. 2010: Simon and Schuster.

3. Esfandyari, A., et al., Application of value stream mapping using simulation to decrease production lead time: a Malaysian manufacturing case. International Journal of Industrial and Systems Engineering, 2011. 8(2), 230-250.

4. Mazzocato, P., et al., Lean thinking in healthcare: a realist review of the literature. Quality and Safety in Health Care, 2010. 19(5), 376-382. 
5. Hines, P., M. Holweg, and N. Rich, Learning to evolve: a review of contemporary lean thinking. International journal of operations \& production management, 2004. 24(10), 994-1011.

6. Danjou, C., et al. PLM-Based Approach for Integration of Product Safety in Lean Development. in IFIP International Conference on Product Lifecycle Management. 2016. Springer.

7. Baines, T., et al., State-of-the-art in lean design engineering: a literature review on white collar lean. Proceedings of the Institution of Mechanical Engineers, Part B: Journal of Engineering Manufacture, 2006. 220(9), 1539-1547.

8. Melton, T., The benefits of lean manufacturing: what lean thinking has to offer the process industries. Chemical engineering research and design, 2005. 83(6), 662-673.

9. Hoppmann, J., et al., A framework for organizing lean product development. Engineering Management Journal, 2011. 23(1), 3-15.

10. Al-Ashaab, A., et al., Development and application of lean product development performance measurement tool. International Journal of Computer Integrated Manufacturing, 2016. 29(3), 342-354.

11. Khan, M.S., et al., Define value: applying the first lean principle to product development. International Journal of Industrial and Systems Engineering, 2015. 21(1), 1-30.

12. Aikhuele, D. and F. Turan, A subjective and objective fuzzy-based analytical hierarchy process model for prioritization of lean product development practices. Management Science Letters, 2017. 7(6), 297-310.

13. Khan, M.S., The construction of a model for lean product development. 2012.

14. Tortorella, G.L., et al., Lean Product Development (LPD) enablers for product development process improvement, in Research Advances in Industrial Engineering. 2015, Springer, 31-57.

15. Tortorella, G.L., et al., Relationships between lean product development enablers and problems. International Journal of Production Research, 2016. 54(10), 2837-2855.

16. Haque, B. and M. Moore, Measures of performance for lean product introduction in the aerospace industry. Proceedings of the Institution of Mechanical Engineers, Part B: Journal of Engineering Manufacture, 2004. 218(10), 1387-1398.

17. León, H.C.M. and J.A. Farris, Lean product development research: Current state and future directions. Engineering Management Journal, 2011. 23(1), 29-51.

18. Anand, G. and R. Kodali, Development of a conceptual framework for lean new product development process. International Journal of Product Development, 2008. 6(2), 190-224.
19. Maksimovic, M., Lean knowledge life cycle framework to support lean product development. 2013.

20. Hines, P., M. Francis, and P. Found, Towards lean product lifecycle management: a framework for new product development. Journal of Manufacturing Technology Management, 2006. 17(7), 866-887.

21. Mohammadi, A., Lean product development-performance measurement system. 2010.

22. Al-Ashaab, A., et al., Lean product development performance measurement tool. 2013.

23. Aikhuele, D.O. and F.M. Turan. A Hybrid Fuzzy Model for Lean Product Development Performance Measurement. in IOP Conference Series: Materials Science and Engineering. 2016. IOP Publishing.

24. Müller-Stewens, B. and K. Möller, Performance in new product development: a comprehensive framework, current trends, and research directions. Journal of Management Control, 2017. 28(2), 157-201.

25. Sajid, M., et al., Manufacturing feature-based cost estimation of cast parts. China Foundry, 2018. 15(6), 464-469.

26. Zhang, B., Design and Implementation of an InfoStore for Key Performance Indicators. 2012.

27. Griffin, A., Metrics for measuring product development cycle time. Journal of product innovation management, 1993. 10(2), 112-125.

28. Wasim, A., et al., An innovative cost modelling system to support lean product and process development. The International Journal of Advanced Manufacturing Technology, 2013. 65(1-4), 165-181.

29. Driva, H., K. Pawar, and U. Menon, Measuring product development performance in manufacturing organisations. International Journal of Production Economics, 2000. 63(2), 147-159.

30. CIA, C., Developing a lean performance score. Strategic Finance, 2009. 91(3), p. 34.

31. Detty, R.B. and J.C. Yingling, Quantifying benefits of conversion to lean manufacturing with discrete event simulation: a case study. International Journal of Production Research, 2000. 38(2), 429-445.

32. Bicheno, J. and M. Holweg, The Lean Toolbox. The Essential Guide to Lean Transformation, Buckingham. 2009, Picsie Books.

33. Kasivisvanathan, R. and A. Chekairi, The productive operating theatre and lean thinking systems. Journal of perioperative practice, 2014. 24(11), 245-248.

34. Radeka, K., The Toyota product development system: integrating people, process and technology by James M. Morgan and Jeffrey K. Liker. Journal of Product Innovation Management, 2007. 24(3), 276-278.

35. Mele, C., The synergic relationship between TQM and marketing in creating customer value. Managing Service Quality: An International Journal, 2007. 17(3), 240-258. 